\title{
Penerapan Algoritma Pencarian Binary Search dan QuickSort pada Aplikasi Kamus Bahasa Palembang Berbasis Web
}

\author{
Andri*) \\ Jurusan Sistem Informasi, Fakultas Ilmu Komputer, Universitas Bina Darma, Palembang \\ Jln. A. Yani No.3 Plaju, Kota Palembang, 30264, Indonesia \\ email: andri@binadarma.ac.id
}

Copyright @2019, Politeknik Harapan Bersama, Tegal

\begin{abstract}
Dictionaries can be used as a means to find meaning and meaning in a word. Palembang language is one of the regional languages in the province of South Sumatra. In their daily lives besides using Indonesian, the Palembang people also use the Palembang language as a means of communication with each other. This study aims to create a web-based Palembang language dictionary application so that it can be accessed using internet media. This dictionary application was created to help people who are not native to the city who live in the city of Palembang. This dictionary application provides a simple user interface that makes it easy for users to use it. In the development of this dictionary application is made using the RAD method. The search algorithm used in word search in a database is using the binary search method. The binary search method has the advantage of linear search. In practice binary search searches by first dividing into two data in a database that has been sorted first. This application can do an effective word search and the information displayed in this application in addition to the meaning and meaning of the word also provides an example of how to use the searched word in Palembang sentences.
\end{abstract}

Abstrak - Kamus dapat digunakan sebagai sarana untuk mencari arti dan makna pada suatu kata. Bahasa Palembang merupakan salah satu bahasa daerah yang ada di provinsi Sumatera Selatan. Dalam kesehariannya selain menggunakan bahasa Indonesia, masyarakat Palembang juga menggunakan bahasa Palembang sebagai sarana komunikasi satu sama lain. Penelitian ini bertujuan untuk membuat aplikasi kamus bahasa Palembang yang berbasis web sehingga dapat diakses menggunakan media internet. Aplikasi kamus ini dibuat untuk membantu masyarakat yang bukan penduduk asli kota yang berdomisili di kota Palembang. Aplikasi kamus ini menyediakan user interface yang sederhana sehingga memudahkan user dalam menggunakannya. Dalam pengembangannya aplikasi kamus ini dibuat dengan menggunakan metode RAD (Rapid Application Development). Algoritma pencarian yang digunakan pada pencarian kata dalam basisdata adalah menggunakan metode binary search. Metode binary search memiliki kelebihan dari linear search. Dalam prakteknya binary search melakukan pencarian dengan terlebih dahulu membagi menjadi dua data dalam basisdata yang sudah terurut terlebih dahulu. Aplikasi ini dapat melakukan pencarian kata yang efektif dan informasi

*) Corresponding Author: (Andri)

Email: andri@binadarma.ac.id yang ditampilkan dalam aplikasi ini selain arti dan makna kata juga memberikan contoh cara penggunaan kata yang dicari dalam kalimat berbahasa Palembang.

Kata Kunci - kamus, binary search, RAD, quicksort

\section{PENDAHULUAN}

Kamus merupakan buku acuan yang memuat kata dan ungkapan yang biasanya disusun menurut abjad dengan disertai keterangan tentang makna, pemakaian dan terjemahannya [1]. Kamus sangat berguna dalam mengenal kata-kata yang disertai dengan maknanya. Dalam kamus biasanya terdapat cara-cara pengucapan kata tersebut serta menerangkan asal kata yang diberikan contoh penggunaannya. Kamus bisa memberikan ilmu pengetahuan berupa kosakata suatu bahasa. Kamus juga dapat memberikan manfaat untuk mengetahui makna kata, lafal kata, ejaan kata, penyukuan kata, serta kebakuan kata dan istilah-istilah penting lainnya.

Indonesia merupakan negara kepulauan yang terdiri dari beraneka ragam suku bangsa, agama dan bahasa. Keanekaragaman ini merupakan kekayaan yang harus terus dilestarikan oleh bangsa Indonesia terutama keanekaragaman bahasa. Bahasa merupakan alat yang digunakan untuk berkomunikasi antara satu orang dengan yang lainnya. Bangsa Indonesia merupakan negara kepulauan yang memiliki bahasa yang berbeda-beda antara satu daerah dengan daerah yang lainnya contohnya bahasa Palembang. Palembang merupakan ibukota provinsi Sumatera Selatan salah satu wilayah yang ada di sumatera bagian selatan. Untuk menjaga kelestariannya maka dalam kesehariannya selain menggunakan bahasa Indonesia masyarakat yang tinggal di Sumatera Selatan juga menggunakan bahasa Palembang sebagai bahasa sehari-hari. Sebagian pendudukan yang tinggal di Palembang bukan merupakan pendudukan asli kota Palembang, banyak warga pendatang dari wilayah lain yang tinggal dan menetap dikota Palembang sehingga sebagian kecil ada yang belum begitu paham dengan bahasa Palembang. Untuk mengatasi kondisi ini maka penulis tertarik untuk membuat sebuah aplikasi kamus bahasa Palembang berbasis web yang nantinya dapat digunakan oleh masyarakat 
yang ingin tahu lebih jauh mengenai bahasa Palembang tersebut.

Algoritma yang digunakan untuk pencarian kata dalam kamus yang akan dibuat akan menggunakan Algoritma pencarian Binary Search. Algoritma pencarian Binary Search dapat diterapkan pada data yang sudah terlebih dahulu dilakukan tahapan pengurutan (Asscending/Descending)[2].

Algoritma pengurutan yang digunakan untuk mengurutkan data dalam basisdata menggunakan menggunakan algoritma quicksort. Algoritma ini sangat cocok untuk mengurutkan data dalam jumlah besar. Algoritma ini melakukan pengurutan data dengan melakukan pemecahan data menjadi partisi-partisi[3]. Dalam memulai iterasi pengurutan, diawali pemilihan elemen dari data, kemudian elemen data tersebut akan diurutkan sedemikian rupa. Strategi yang digunakan dalam pengurutan quicksort adalah divide and conqueror.

\section{PENELITIAN YANG TERKAIT}

Terdapat beberapa penelitian yang terkait dengan dengan penelitian yang ini diantaranya penelitian yang berjudul Implementasi Teknik Binary Search pada Kamus IndonesiaBatak Toba [2]. Pada penelitian aplikasi kamus dibuat menggunakan Bahasa pemrograman berbasis desktop. Dalam artikel ini aplikasi kamus yang dibuat merupakan aplikasi yang berbasis web sehingga dapat diakses oleh banyak user menggunakan media internet.

Penelitian berikutnya yang terkait adalah penelitian yang berjudul A Review On Comparision Of Binary Search And Linear Search [4]. Dalam penelitian membahas tentang perbandingan algoritma pencarian Binary Search dan Linear Search.

\section{RAPID APLLICATION DEVELOPMENT \& ALGORITMA QUICKSORT}

\section{A. Rapid Application Development (RAD)}

RAD merupakan suatu metode pendekatan yang berorientasi objek untuk menghasilkan sebuah sistem dengan tujuan utamanya adalah mempersingkat waktu pengembangan dan prosesnya serta sesegera mungkin memberdayakan perangkat lunak sistem secara cepat dan tepat waktu[7].

\section{B. Algoritma Quicksort}

Algoritma quicksort merupakan algoritma yang digunakan untuk mengurutkan item dalam sebuah array dengan cepat, tidak peduli seberapa besar array tersebut. Algoritma ini bekerja relatif baik untuk set data kecil ataupun besar dan mudah untuk diimplementasikan dengan kompleksitas waktu yang sedikit. Algoritma quicksort melakukan perulangan dengan membagi sebuah array besar menjadi dua bagian kecil. Langkah-langkah dalam algoritma quicksort terdiri dari:

- Penentuan data yang akan diurutkan

- Memilih elemen pivot, elemen pivot ini sementara yang digunakan sebagai acuan selesainya proses partisi.

- Kemudian memilih elemen pertama dan elemen terakhir.

- Selanjutnya melakukan pertukaran elemen berdasarkan pergerakan dari kiri ke kanan dan dari kanan ke kiri sampai ditemukan nilai kiri $>=$ pivot dan nilai kanan $<=$ pivot.

Dengan cara ini, seluruh elemen data diurutkan secara rekursif menggunakan algoritma yang sama. Pemilihan pivot atau elemen nilai tengah dalam algoritma quicksort sangat menentukan apakah algoritma tersebut menghasilkan performa yang baik atau tidak. Ada beberapa cara dalam menentukan elemen pivot diantaranya:

a) Menentukan pivot dari elemen yang pertama, terakhir atau elemen tengah dalam tabel. Cara seperti ini hanya bak jika elemen dalam tabel tersusun secara acak.

b) Menentukan pivot secara acak dari salah satu elemen tabel.

c) Menentukan pivot berdasarkan elemen median dari tabel. Ini adalah cara yang palng tepat karena hasil partisi akan menghasilkan dua bagian tabel yang berukuran seimbang. Kompleksitas waktu yang diberikan minimum.

Pseudocode untuk menentukan pivot quicksort adalah sebagai berikut:

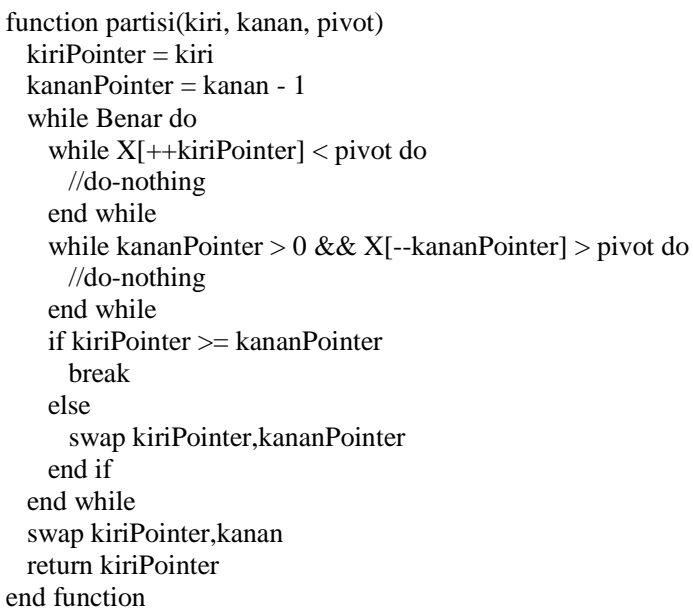

Setelah proses penentuan pivot selanjut algoritma quicksort dapat dilihat dari pseudocode berikut ini:

procedure QS(kiri, kanan)

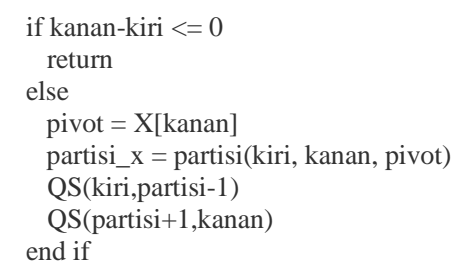

end procedure

\section{Algoritma Pencarian}

Menurut Kamus Besar Bahasa Indonesia pencarian merupakan proses, cara, atau perbuatan mencari. Dalam ilmu komputerisasi pencarian adalah kegiatan untuk mendapatkan suatu bentuk data atau informasi yang tersimpan di media penyimpanan[1]. Algoritma pencarian adalah langkahlangkah untuk mencari data atau informasi yang tersimpan menggunakan kata kunci. Dalam algoritma pencarian kata kunci digunakan sebagai masukan yang akan dicari kemudian diproses dan menghasilkan kesimpulan ditemukan atau tidak ditemukan. Algoritma pencarian dapat berupa pencarian sekuensial dan pencarian biner [8]. 


\section{Binary Search}

Binary search merupakan sebuah metode pencarian data yang telah terurut. Dalam metode ini semua elemen data yang telah terurut akan diuji satu per satu sampai ditemukan elemen yang diinginkan. Pencarian pada data yang telah diurutkan akan menghasilkan pencarian yang cepat. Algoritma ini digunakan untuk kebutuhan pencarian dengan waktu yang cepat[9]. Cara kerja algoritma pencarian ini dengan membagi data menjadi dua bagian. Binary search merupakan teknik untuk menemukan nilai tertentu yang tersimpan dalam sebuah array.

Pencarian binary search ini dilakukan untuk memperkecil jumlah operasi perbandingan antara data yang akan dicari dengan data yang ada dalam tabel. Prinsipnya melakukan pembagian ruang pencarian secara berulang-ulang sampai data yang cari ditemukan atau sampai tidak dapat dibagi lagi dengan kata lain data yang dicari tidak ditemukan.

Pseudocode metode binary search adalah sebagai berikut:

Procedure pencarian_biner

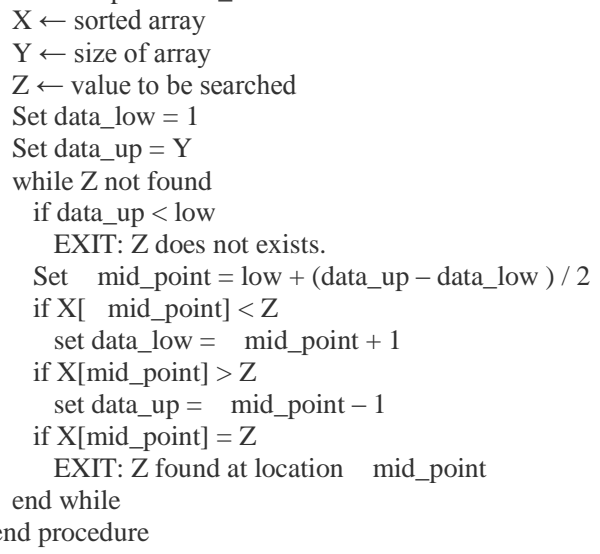

Penjelasan dari pseudocode binary search dapat dijelaskan dalam langkah-langkah berikut:

1) Mula-mula ditentukan batasbawah (data_low) $=1$ dan batasatas (data_up) $=\mathrm{N}$ dari array yang sudah terurut

2) Cari posisi data tengah (mid_Point) dengan rumus: data_low + (data_up - data_low)/2

3) Data (Z) yang dicari dibandingkan dengan data tengah (mid_Point)

4) Jika lebih kecil, proses dilakukan kembali tetapi data_up dianggap sama dengan posisi tengah -1\{$ data_up $=$ mid_Point -1 \}

5) Jika lebih besar, proses dilakukan kembali tetapi data_low dianggap sama dengan posisi tengah +1\{$ data_low $=$ mid_Point +1$\}$

6) Demikian seterusnya sampai data tengah sama dengan data yang dicari (mid_Point $=$ Z)

Penjelasan dapat dilihat pada contoh berikut, misalkan akan dicari angka 29 pada sekumpulan data berikut: $\{8,12,17,24,25,29,31,33,40,42\}$

1) Mencari data tengah dengan rumus data_mid = data_low $+($ data_high - data_low $) / 2$ data_mid $=0+$ $(9-0) / 2=4$ maka akan didapat data tengah adalah 25 .

2) Kemudian data yang dicari 29 dibandingkan dengan data tengah (data_mid) yang diperoleh yaitu 25 .
3) Hasil perbandingan $29>25$ maka set data_low $=$ data_mid +1 , data_mid $=$ data_low + (data_high data_low) $/ 2=7$, Nilai data_mid sekarang adalah 33

4) Kemudian data yang dicari 29 dibandingkan dengan data tengah (data_mid) yang peroleh yaitu 33 .

5) Hasil perbandingan $29<33$ maka set data_low = data_mid -1 , set data_up $=$ data_mid -1 , data_mid $=$ data_low $+($ data_up - data_low $) / 2=6$, Nilai data_mid sekarang adalah 31

6) Kemudian data yang dicari 29 dibandingkan dengan data tengah (data_mid) yang diperoleh yaitu 31 .

7) Hasil perbandingan $29<31$ maka set data_low = data_mid-1, set upperBoud = data_mid -1 , data_mid $=$ data_low + (data_up - data_low $)=5$, nilai mid sekarang adalah 29

8) Kemudian data yang dicari 29 dibandingkan dengan data tengah (data_mid) yang diperoleh yaitu 29

9) Hasil perbandingan $29=29$, data ditemukan di posisi 5 , maka perulangan berhenti.

\section{METODE PENELITIAN}

Dalam pembuatan aplikasi kamus bahasa Palembang berbasis web metode penelitian yang digunakan adalah metode Rapid Applicatioan Development. Metode RAD sangat tepat digunakan untuk pengembangan perangkat lunak dengan kebutuhan mendesak yang memerlukan waktu yang singkat[5]. Pengembangan perangkat lunak menggunakan metode RAD memiliki beberapa tahapan seperti Requirement Planning, Design System dan Implementation[6]. Pada tahap pertama requirement planning, pemakai dan sistem analis akan melakukan pertemuan untuk melakukan identifikasi tujuan dari sistem serta menentukan kebutuhan dari sistem yang akan dibangun. Tahap kedua design system, yaitu akan melakukan rancangan terhadap sistem berdasarkan kebutuhan sistem yang sudah didefinisikan pada tahap pertama. Selanjutnya tahap ketiga melakukan implementasi sistem yaitu membuat atau mengembangkan desain program berdasarakan rancangan yang telah dibuat sebelumnya.

RAD merupakan suatu metode pendekatan yang berorientasi objek untuk menghasilkan sebuah sistem dengan tujuan utamanya adalah mempersingkat waktu pengembangan dan prosesnya serta sesegera mungkin memberdayakan perangkat lunak sistem secara cepat dan tepat waktu[7].

Metode RAD memiliki beberapa keunggulan karena tahapan dalam RAD mengikuti tahapan pada umumnya, tetapi mempunyai kelebihan penggunaan kembali komponen yang sudah ada (reusable object).

\section{HASIL DAN PEMBAHASAN}

Berdasarkan tahapan requirement system, diidentifikasi kebutuhan sistem aplikasi kamus berupa user interface berbasis web. Proses pencarian kata yang tersimpan dalam sebuah basisdata menerapkan algoritma pencarian binary search sehingga dihasilkan membutuhkan waktu yang cepat dan efisien. Aplikasi kamus bahasa Palembang ini dibuat dengan menggunakan bahasa pemrograman web PHP dan database yang digunakan untuk menyimpan kata bahasa Palembang adalah MySQL. Untuk menyimpan daftar kata bahasa Palembang dan Indonesia dalam aplikasi kamus ini dibuat sebuah tabel yang terdiri dari tiga kolom yang berisi 
daftar kata bahasa Palembang dan bahasa Indonesia serta tata cara penggunaannya dalam kalimat.

Kamus ini akan menterjemahkan kata perkata yang diinputkan dalam sistem, kemudian kata tersebut akan dicari padanannya dalam database dengan menerapkan algoritma pencarian binary search. Algoritma binary search diterapkan pada pencarian data dalam tabel ketika pengguna menekan tombol Terjemah. Alur proses dari aplikasi kamus ini dapat dilihat pada flowchart Gbr. 1

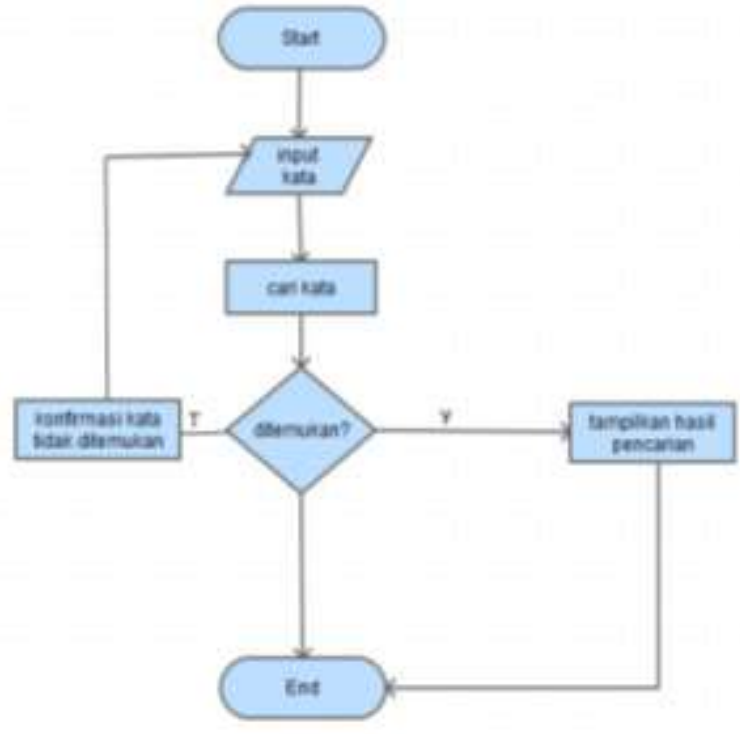

Gbr. 1 Flowchart Aplikasi

Tampilan utama aplikasi kamus bahasa Palembang berbasis web yang telah dibuat dalam penelitian dapat dilihat pada Gbr.2. Aplikasi ini menyediakan user interface yang menyediakan fungsi input kata dalam bahasa Palembang. Kata yang digunakan sebagai key word diinputkan user kemudian dicari padanan katanya dalam basisdata dengan menggunakan metode binary searching.

Algoritma pencarian binary search akan dijalankan ketika user melakukan pencaria kata. Sebelum proses pencarian kata, terlebih dahulu akan dilakukan pengurutan data yang menerapkan algoritma quicksort. Hasil pencarian berupa arti kata dalam bahasa Indonesia dan penggunaannya dalam bahasa Palembang.

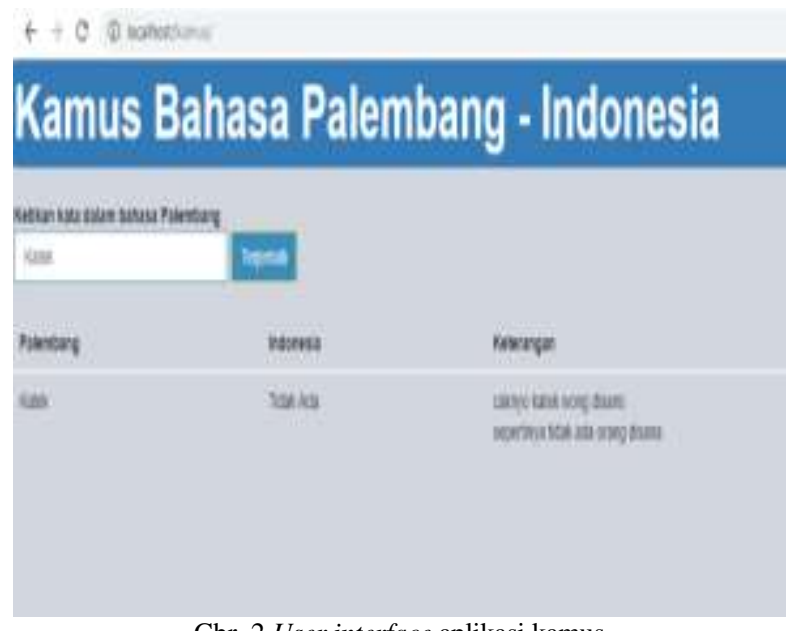

Gbr. 2 User interface aplikasi kamus
Teknik pencarian binary search akan melakukan pengurutan data terlebih dahulu sebelum dilakukan proses pencarian. Dalam sistem ini terdapat sebuah tabel yang berfungsi untuk menyimpan daftar kata-kata bahasa Palembang beserta arti dalam bahasa Indonesia. Berikut ini adalah contoh daftar kata kamus bahasa Palembang.
1) amen $\rightarrow$ kalau, jika
2) cekel $\rightarrow$ pegang
3) balek $\rightarrow$ kembali,pulang
4) gancang $\rightarrow$ cepat
5) calak $\rightarrow$ cerdik
6) abang $\rightarrow$ merah
7) campak $\rightarrow$ jatuh
8) dewek $\rightarrow$ sendiri
9) denget $\rightarrow$ sebentar
10) enjok $\rightarrow$ beri

Daftar kata tersebut belum dilakukan pengurutan, proses pengurutan akan dilakukan ketika algoritma pencarian binary search diterapkan. Berikut ini adalah contoh penerapan algoritma binary search untuk mencari arti kata 'enjok' pada urutan 8 (indeks array dimulai dari 0) dalam aplikasi kamu bahasa Palembang.

Langkah penyelesaian:

1. Proses pengurutan data

abang $\rightarrow$ merah

amen $\rightarrow$ kalau, jika

balek $\rightarrow$ kembali,pulang

calak $\rightarrow$ cerdik

campak $\rightarrow$ jatuh

cekel $\rightarrow$ pegang

denget $\rightarrow$ sebentar

dewek $\rightarrow$ sendiri

enjok $\rightarrow$ beri

gancang $\rightarrow$ cepat

diketahui : low $=0$ (abang), high $=9$ (gancang)

2. Menghitung jumlah data $($ count $=10)$

3. Menentukan nilai tengah

set mid_Point $=$ data_low $+($ data_high - data_low $) / 2$ set mid_Point $=0+(9-0) / 2=4$ (campak)

4. Mengecek apakah kata "enjok"[8] = "campak"[4] (false)

5. mid_Point $<$ kata, maka set data_low $=$ mid_Point + 1 (data_low $=5)$

6. set mid_Point $=5+(9-5) / 2 \rightarrow 7$ (dewek)

7. Mengecek apakah kata "enjok"[8] = "dewek"[7] (false)

8. $\quad$ mid_Point $<$ kata, maka set data_low $=$ mid_Point + $1($ low $=8)$

9. set mid_Point $=8+(9-8) / 2 \rightarrow 8$ (enjok)

10. Mengecek apakah kata "enjok"[8] = "enjok"[8] (true)

11. Kata ditemukan, perulangan berhenti.

\section{KESIMPULAN}

Penelitian ini menghasilkan sebuah aplikasi kamus bahasa Palembang berbasis web. Aplikasi ini dibuat untuk membantu masyarakat dalam belajar dan memahami bahasa Palembang yang merupakan bahasa daerah salah satu kota yang ada di 
provinsi Sumatera Selatan. Penerapan algoritma pencarian kata dalam basisdata menggunakan teknik binary search sangat tepat karena menghasilkan waktu pencarian yang cepat dan efisien. Untuk mempermudah menerapkan algoritma pencarian binary search yang mengharuskan data harus terurut terlebih dahulu maka digunakan teknik pengurutan quicksort. Metode quicksort ini sangat tepat digunakan karena data yang digunakan cukup besar.

Saran bagi penelitian berikutnya dapat menggunakan algoritma pencarian lain untuk melihat perbandingan efisiensi waktu pencarian. Selain itu aplikasi kamus dapat dikembangkan lebih lanjut berupa pemberian fasilitas koreksi penulisan kata yang akan dicari.

\section{DAFTAR PUSTAKA}

[1] KBBI, Kamus Besar Bahasa Indonesia (KBBI). [Online] Available: http://kbbi.web.id/kamus, [Accessed: 15- Nov-2018].

[2] G. Syahputra and B. Sinurat, "Implementasi Teknik Binary Search Pada Kamus Indonesia - Batak Toba,” J. Informatics Pelita Nusant. vol. 1 , no. 1 , pp. $28-37,2016$.
[3] I. M. Alturani, A. Mahmoud, and I. Alturani, "Review on Sorting Algorithms A Comparative Study,” Int. J. Comput. Sci. Secur., vol. 7, no. 3, pp. 120-126, 2013.

[4] A. Mehta, A. Saxena, J. Patel, and A. Thanna, "a Review on Comparision of Binary Search and Linear Search,” Int. J. Eng. Sci. Manag. Res., vol. 2, no. 10, pp. 85-89, 2015.

[5] S. Kosasi, "Penerapan Rapid Application Development Dalam Sistem Perniagaan Elektronik Furniture,” Citec J., vol. 2, no. 4, pp. 265-276, 2015.

[6] S. Aswati and Y. Siagian, "Model Rapid Application Development Dalam Rancang Bangun Sistem Informasi Pemasaran Rumah ( Studi Kasus: Perum Perumnas Cabang Medan," Sesindo, pp. 317-324, 2016.

[7] G. W. Sasmito and S. Wiyono, "Implementation of Rapid Application Development Method on Academic Staff System of Harapan Bersama Polytechnic," Int. J. Comput. Trends Technol., vol. 50, no. 1, pp. 11$13,2017$.

[8] V. Mutiawani, "Hashtable Sebagai Alternatif Dari Algoritma Pencarian Biner Pada Aplikasi E-Acesia," J. Inform. Univ. Syiah Kuala, vol. 8, no. 2, pp. 943-952, 2014.

[9] A. Oommen and C. Pal, "Binary search algorithm," Codility Limited., vol. 1, no. x, pp. 1-4, 2015. 